\title{
Chapter 14 \\ The Dutch Referendum \\ on the EU-Ukraine Association \\ Agreement: Legal Implications \\ and Solutions
}

\section{Guillaume Van der Loo}

\begin{abstract}
This chapter will analyse the legal consequences of the outcome of the Dutch referendum of 6 April 2016 concerning the EU-Ukraine Association Agreement. The result of the referendum raised the question whether a single Member State can 'veto' the entry into force of a bilateral association agreement. Due to the unprecedented nature of this situation and the fact that the EU Treaties do no give a clear answer to this question, many issues related to the non-ratification of mixed agreements remain unclear. Therefore, after briefly analysing the 'mixed' nature of the EU-Ukraine Association Agreement and its current legal status, the legal consequences of the Dutch 'tegen' (against) are explored, focussing on the provisional application of the agreement. Finally, the solution of the Dutch government to deal with the outcome of the referendum, and some alternatives, are discussed.
\end{abstract}

Keywords EU • Ukraine - Association Agreement - Referendum - Provisional application • Mixed agreements • Ratification

\section{Contents}

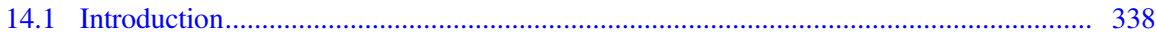

14.2 Mixed (Association) Agreements...................................................................... 338

14.3 The Current Legal Status of the EU-Ukraine Association Agreement....................... 340

14.4 Legal Consequences of the Referendum ....................................................... 342

FWO postdoctoral researcher at the Ghent European Law Institute, and researcher at the Centre for European Policy Studies (CEPS).

G. Van der Loo $(\bowtie)$

Ghent European Law Institute, Ghent University, Ghent, Belgium

e-mail: guillaume.vanderloo@ugent.be

G. Van der Loo

Centre for European Policy Studies (CEPS), Brussels, Belgium

(C) T.M.C. ASSER PRESS and the authors 2017

M. Kuijer and W. Werner (eds.), Netherlands Yearbook of International

Law 2016, Netherlands Yearbook of International Law 47,

DOI 10.1007/978-94-6265-207-1_14 
14.5 The Way Out 345

14.5.1 The Decision of the Heads of State or Government, Meeting Within the European Council

14.5.2 Alternative Options................................................................................. 348

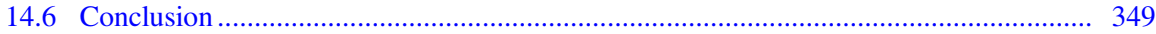

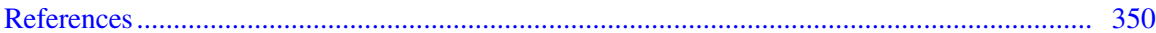

\subsection{Introduction}

On 6 April 2016 the EU-Ukraine Association Agreement was rejected in the Netherlands in an advisory referendum, which was organised pursuant to the Dutch Advisory Referendum Act (DRA), with $61.1 \%$ of the votes. The fact that this advisory referendum, which had a low turnout of $32 \%$, could complicate the ratification procedure of a landmark international agreement for the entire European Union raises several legal and political questions. It is actually the first time that a single Member State is (potentially) unable to ratify a bilateral EU mixed agreement (i.e. an international agreement that is concluded by the EU and its Member States on the one hand, and a third State on the other). ${ }^{1}$ Because the political character of this referendum and the content and geopolitical implications of the Association Agreement have already been discussed elsewhere, ${ }^{2}$ this chapter will mainly focus on the legal implications of this referendum for the EU-Ukraine Association Agreement. After briefly analysing the 'mixed' nature of the EU-Ukraine Association Agreement and its current legal status, the legal consequences of the Dutch 'tegen' (against) are explored. Finally, the solution of the Dutch government to deal with the outcome of the referendum, and some alternatives, are discussed.

\subsection{Mixed (Association) Agreements}

The EU-Ukraine Association agreement is concluded as a mixed agreement. These are agreements concluded by third parties, on the one hand, and the EU and its Member States, on the other, because these agreements cover elements of both EU and Member State competence. The procedural consequence of 'mixity' is that the 28 Member States have to ratify the agreement alongside the EU, each according to their own 'constitutional' ratification procedures. Mixed agreements are a common feature in the EU's external relations. The fact that the expression 'mixed

\footnotetext{
${ }^{1}$ For a detailed analysis of mixed agreements, see Heliskoski 2001. For examples of exceptionally long ratification procedures, see Rosas 2014.

${ }^{2}$ For a comprehensive overview of the EU-Ukraine Association Agreement, see Van der Loo 2016a.
} 
agreements' was absent from the original EEC Treaty did not prevent one of the first bilateral agreements concluded by the Community, the Association Agreement with Greece of 1961, from being mixed. ${ }^{3}$ Also, the most recent agreement signed by the EU, the EU-Canada Comprehensive Economic and Trade Agreement (CETA), was categorized as a mixed agreement.

Traditionally, association agreements are concluded as mixed agreements for a number of reasons. First, they are typically comprehensive in nature providing a general framework for cooperation involving areas belonging to EU and Member State competences. Second, mixity is often a pragmatic solution to avoid internal competence battles among EU institutions and Member States. Third, the political importance of association agreements explains why Member States prefer to be a contracting party in their own right, in addition to the EU. It not only endows them with additional bargaining power during the negotiations and in the ratification process but also upholds their visibility vis-à-vis third countries. ${ }^{4}$ The mixed nature of association agreements creates an additional reinforced unanimity as the procedural legal basis of such agreements is, inter alia, Article 218(8) TFEU, ${ }^{5}$ which already requires unanimity in the Council for the conclusion of association agreements.

However, from a strict legal point of view, there is no requirement for association agreements to be mixed. As Rosas notes,

\begin{abstract}
generally speaking, [association agreements] do not need to be mixed, as the Treaty of Lisbon has widened the scope of the common commercial policy and has introduced a fairly wide formulation of supervening exclusivity in Article 3(2) TFEU and what seems to ban an even wider formulation of treaty-making powers in general in Article 216(1) TFEU as well as a more integrated CFSP competence also covered by Article 216 TFEU on Union treaty-making powers. ${ }^{6}$
\end{abstract}

Moreover, since the Lisbon Treaty ${ }^{7}$ abolished the pillar structure and created a single legal personality for the EU, the inclusion of Common Foreign and Security Policy (CFSP) provisions in a broader framework agreement such as the EU-Ukraine Association Agreement does not automatically require mixity. In order to render mixity legally more defendable, clauses perceived to fall under Member States competences have been inserted into association agreements or bilateral agreements of a general nature, such as provisions on political dialogue or cultural cooperation.

Hence, the choice for mixity 'is not necessarily a result of legal orthodoxy but frequently the consequence of crude political interests on behalf of the Member

\footnotetext{
${ }^{3}$ Maresceau 2010.

${ }^{4}$ Ibid.

${ }^{5} 2012$ Treaty on the Functioning of the European Union (Consolidated version), C 326/47 (TFEU).

${ }^{6}$ Rosas 2014, at 24.

${ }^{7} 2007$ Treaty of Lisbon amending the Treaty on European Union and the Treaty establishing the European Community, 2702 UNTS 3.
} 
States'. ${ }^{8}$ This was recently illustrated during the process of the conclusion of the Stabilisation and Association Agreement with Kosovo. Because not all Member States recognise Kosovo as an independent State, the EU-Kosovo Association Agreement was concluded as an 'EU-only' agreement. ${ }^{9}$ This option prevents that the EU Member States (including those who do not recognise Kosovo) need to ratify the agreement, which would entail a de facto recognition of Kosovo.

\subsection{The Current Legal Status of the EU-Ukraine Association Agreement}

After the Maidan revolution, which was sparked in November 2013 by the unexpected last-minute decision of the previous Ukrainian government not to sign the agreement, the EU-Ukraine Association Agreement was finally signed in March and June 2014. However, several procedural steps were-and still are-required before the agreement can fully enter into force. For example, the European Parliament needs to give its consent for association agreements, ${ }^{10}$ which occurred for the EU-Ukraine Association Agreement simultaneously with the Ukrainian Verkhovna Rada on 16 September 2014.

As noted above, mixed agreements also require the ratification of all 28 Member States. Such a ratification procedure usually takes 3-4 years. However, in order to circumvent this long ratification process, most mixed agreements provide for the possibility of provisional application. Article 486 of the EU-Ukraine Association Agreement indeed States that the parties 'agree to provisionally apply this Agreement in part, as specified by the Union, [...] and in accordance with their respective internal procedures and legislation as applicable'. ${ }^{11}$ A legal basis for the provisional application of international agreements concluded by the EU was included in the Amsterdam Treaty ${ }^{12}$ (now Article 218(5) TFEU). It reflects Article 25 of the Vienna Convention on the Law of Treaties (VCLT), ${ }^{13}$ according to which a treaty may provide for such provisional application or the negotiating States may agree to it. Another option which was used by the EU to alleviate the negative effect of mixity is to sign and conclude formally a separate agreement (often called an 'Interim Agreement') incorporating only those parts of the main agreement that fall squarely within the Union (before the Lisbon Treaty: 'Community') competences. ${ }^{14}$

\footnotetext{
${ }^{8}$ Van Elsuwege 2017.

9 Ibid.

${ }^{10}$ Article 218(6)(a)(i) TFEU.

${ }^{11}$ Article 486(3) EU-Ukraine Association Agreement.

121997 Treaty of Amsterdam Amending the Treaty on European Union, 2700 UNTS 161.

131969 Vienna Convention on the Law of Treaties, 1155 UNTS 331 (VCLT).

${ }^{14}$ On such 'Interim Agreements', see Flaesch-Mougin and Bosse-Platière 2014.
} 
Given the political significance of the Agreement, the Council agreed on an exceptional wide scope of provisional application of the EU-Ukraine Association Agreement. Usually, the provisional application or 'Interim Agreements' of association agreements or other framework agreements only cover the trade(-related) elements of the agreement. But in the EU-Ukraine Association Agreement, the scope of the provisional application goes beyond the trade part of the agreement (i.e. the deep and comprehensive free trade area (DCFTA)) and also includes the entire titles on General Principles, Financial Cooperation and General and Final Provisions and provisions regarding political dialogue, rule of law and movement of persons and economic and sector cooperation. ${ }^{15}$ It has to be noted that the Commission even proposed a broader scope for provisional application, including, inter alia, the entire title on Political Dialogue and Reform, Political Association, Cooperation and Convergence in the field of Foreign and Security Policy. ${ }^{16}$ However, the Member States, in particular the UK, triggered objections against the proposed scope of provisional application and agreed on a more limited-but still extensive- - scope of provisional application. ${ }^{17}$

This broad scope raised questions on the potential provisional application of 'mixed' elements of the agreement. Evidently, only the provisions falling under EU competences (exclusive or shared) can be applied provisionally by the Council Decision for signature and provisional application. This problem is partially circumvented by the fact that the provisions responsible for the mixity of an agreement are never specifically indicated in the relevant Council Decision (or another document), mainly because the Commission and the Council would find it very difficult to agree on such a clear delineation of competences. The provisional application of mixed elements is also addressed in the Council Decisions on the signing and provisional application of the EU-Ukraine Association Agreement as they state that the listed provisions for provisional application shall be applied provisionally 'only to the extent that they cover matters falling within the Union's competence,

\footnotetext{
${ }^{15}$ Combined reading of the Council Decision of 17 March 2014 on the signing, on behalf of the European Union, and provisional application of the Association Agreement between the European Union and the European Atomic Energy Community and their Member States, of the one part, and Ukraine, of the other part, as regards the Preamble, Article 1, and Titles I, II and VII thereof, 2014/295/EU (Council Decision 2014/295/EU) and Council Decision of 23 June 2014 on the signing, on behalf of the European Union, and provisional application of the Association Agreement between the European Union and the European Atomic Energy Community and their Member States, of the one part, and Ukraine, of the other part, as regards Title III (with the exception of the provisions relating to the treatment of third-country nationals legally employed as workers in the territory of the other Party) and Titles IV, V, VI and VII thereof, as well as the related Annexes and Protocols, 2014/668/EU (Council Decision 2014/668/EU).

${ }^{16}$ European Commission, Proposal for a Council Decision on the signing, on behalf of the European Union, and provisional application of the Association Agreement between the European Union and its Member States, of the one part, and Ukraine, of the other part, $\operatorname{COM}(2013) 289$ final, 15 May 2013.

${ }^{17}$ European Commission, 'Note à l'attention des membres du GRI', 6 June 2014 (not public, on file with the author).
} 
including matters falling within the Union's competence to define and implement a common foreign and security policy'. ${ }^{18}$ Their preambles also indicate that 'the provisional application of parts of the Agreement does not prejudge the allocation of competences between the Union and its Member States in accordance with the Treaties.'

The initiation of the provisional application of a mixed agreement requires at the EU's side the adoption of a Council Decision. Because the provisional application covers in this case an association agreement, unanimity is required in the Council for the adoption of this Decision. ${ }^{19}$ Moreover, a practice has been developed by the Commission and the Council to only initiate the provisional application of mixed agreements that require the consent of the European Parliament after having received such a consent. ${ }^{20}$ The provisional application of the EU-Ukraine Association Agreement started on 1 November 2014, however, the provisional application of the DCFTA was postponed until 1 January 2016 in response to political pressure from Russia. ${ }^{21}$

\subsection{Legal Consequences of the Referendum}

Meanwhile, all the EU Member States have ratified the EU-Ukraine Association Agreement, with one notable exception. In the Netherlands, the Approval Act for the ratification of the agreement was adopted by the House of Representatives (Second Chamber) on 7 April 2015 and the Senate (First Chamber) on 7 July 2015. ${ }^{22}$ However, the entry into force of this Approval Act (and thus the Netherland's ratification) was suspended due to the start of the referendum procedure under the DRA.

It is now claimed that the Dutch voters have rejected the Association Agreement in the referendum, but the reality is more complex. The subject of the referendum was actually not the EU-Ukraine Association Agreement as such, but the Approval

\footnotetext{
${ }^{18}$ See for example Article 4 of Council Decision 2014/295/EU and Article 4 of Council Decision 2014/668/EU.

${ }^{19}$ The Council Decisions for the signature and provisional application of the EU-Ukraine Association Agreement (ibid) have as a legal basis, inter alia, subparagraph 2 of Article 218(8) TFEU, which requires unanimity for the conclusion of association agreements.

${ }^{20}$ In a Resolution adopted on 23 October 2013, the European Parliament called for the provisional application of the EU-Ukraine Association Agreement immediately upon signature, clearing the way for provisional application of the agreement. Moreover, the European Parliament gave its consent already on 16 September 2014, before the provisional application of the EU-Ukraine Association Agreement was (partially) initiated on 1 November 2014.

${ }^{21}$ For an overview of this process, see Van der Loo 2016a.

${ }^{22}$ Staatsblad van het Koninkrijk der Nederlanden, Wet van 8 juli 2015, houdende goedkeuring van de op 27 juni 2014 te Brussel tot stand gekomen Associatieovereenkomst tussen de Europese Unie en de Europese Gemeenschap voor Atoomenergie en haar lidstaten, enerzijds, en Oekraine, anderzijds, (2015) Nr. 315, 28 July 2015.
} 
Act that ratified the agreement. This law was the legal instrument by which the Kingdom of the Netherlands ratified the Member States' elements of the 'mixed' EU-Ukraine Association Agreement. Most likely, few Dutch voters were aware of this subtle technicality when they voted on 6 April. In fact, the situation is even more abstract as nowhere in the agreement or in the Council Decisions for signature of the agreement is it indicated which provisions of the agreement fall under exclusive Member State (and thus Dutch) competences. As noted above, such a delineation is traditionally avoided to prevent competence conflicts between the European Commission and the European Parliament on the one hand, and the Council and the Member States on the other. The scope of the provisional application of the agreement already gives an indication of which elements are not considered as Member States' competences, as only provisions falling under the EU competences can be provisionally applied. However, this does not give a complete and exact overview.

According to the DRA, the Dutch government now has to decide whether it will propose a law that repeals the Approval Act, or a law that confirms it. In either scenario, approval by the Parliament is required, but this 'repealing' or 'confirming' law cannot again be the subject of a new referendum.

In any case, the immediate legal consequences of the no-vote are limited. As long as the Netherlands does not ratify the Association Agreement, it cannot fully enter into force. The agreement can only enter into force if all the contracting Parties (thus the EU, the 28 Member States and Ukraine) have ratified it. ${ }^{23}$ Because the Union only ratifies a mixed agreement after all the Member States have done so, also the EU still needs to conclude the agreement. ${ }^{24}$ However, this has no impact on the provisional application of the agreement, which theoretically can continue indefinitely because there is no 'deadline' for the provisional application. The Dutch Foreign Minister has replied to a parliamentary question that it would not make sense to continue with the provisional application of the Association Agreement in the event it is not ratified. ${ }^{25}$ It would indeed be paradoxical to indefinitely provisionally apply an agreement that it is not ratified, especially considering that the aim of provisional application is to bridge the temporal gap between signature and ratification of an agreement. However, the Council Decisions on the signing of the agreement do not specify an expiry date for the provisional application. Moreover, Member States cannot terminate the Union's provisional application of the agreement. The provision in the

\footnotetext{
${ }^{23}$ Article 486 EU-Ukraine Association Agreement.

${ }^{24}$ However, there are numerous examples of multilateral mixed agreements concluded by the EU, but not by all Member States. On this practice, see Heliskoski 2001.

${ }^{25}$ Tweede Kamer der Staten Generaal, Vragen van het lid Omtzigt (CDA), Verhoeven (D66) en Voordewind (ChristenUnie) aan de Minister van Buitenlandse Zaken over de voorlopige inwerkingtreding van het associatieverdrag tussen de EU en Oekraïne (ingezonden 5 januari 2016) -Antwoord van Minister Koenders (Buitenlandse Zaken) (ontvangen 5 februari 2016) (Minister of Foreign Affairs Bert Koenders, Answers to Members Omtzigt, Verhoeven, Voordewind on the provisional application of the EU-Ukraine Association Agreement), (2015-2016) Nr. 1401, 5 February 2016.
} 
Association Agreement on provisional application (Article 486) states that either party may terminate the provisional application of the agreement. However, only the EU provisionally applies a part of the agreement (i.e. a large part of the provisions falling under Union competences), and not the Member States. As recognised by the Court of Justice of the European Union (CJEU), the decision authorising the Union's provisional application is adopted by the Council, 'and no competence is granted to the Member States for the adoption of such a decision'. ${ }^{26}$ The termination of the Union's provisional application by a Member State would be clearly in breach with the principle of autonomy of the EU institutions and would be at odds with the duty of sincere cooperation, enshrined in Article 4(3) TEU. ${ }^{27}$ Because Article 218 TFEU does not provide clear rules on how to terminate the provisional application of an agreement, the same procedure to initiate the provisional application should be followed. For association agreements (such as the EU-Ukraine Association Agreement) this would require at the EU's side a unanimous Decision of the Council. Therefore, this 'reversed unanimity' would imply that no single EU Member State (e.g. the Netherlands) can halt the provisional application of the agreement.

The situation where one Member State would be unable to ratify a mixed agreement is unprecedented. However, in the context of the signature of (EU-Canada) CETA some relevant statements and declarations were adopted by EU institutions and Member States with regard to the agreement's provisional application. ${ }^{28}$ The signature of the mixed CETA Agreement was in October 2016 in limbo for almost two weeks because the Belgian region of Wallonia refused to give its consent to the federal Belgian government to sign the deal. In order to get the Walloon government on board, numerous statements and declarations have been adopted, mainly to accommodate the concerns of the Walloon government. ${ }^{29}$ The Council adopted also the following statement relating to the provisional application of CETA:

If the ratification of CETA fails permanently and definitively because of a ruling of a constitutional court, or following the completion of other constitutional processes and formal notification by the government of the concerned state, provisional application must be and will be terminated. The necessary steps will be taken in accordance with EU procedures. ${ }^{30}$

\footnotetext{
${ }^{26}$ Case C-28-12 (European Commission v Council), ECJ (Grand Chamber), Judgment, ECLI:EU: C:2015:282, 28 April 2015.

${ }^{27}$ Ibid.

${ }^{28}$ These statements and declarations are published on the website of the Council: European Council-Council of the European Union (2016) EU-Canada trade agreement: Council adopts decision to sign CETA, 28 October 2016, http://www.consilium.europa.eu/en/press/press-releases/ 2016/10/28-eu-canada-trade-agreement/?utm_source=dsms-auto\&utm_medium=email\&utm_ campaign=EU-Canada+trade+agreement $\% 3 a+C o u n c i l+a d o p t s+d e c i s i o n+t o+s i g n+C E T A, a c c e s-$ sed 9 March 2017.

${ }^{29}$ For an analysis of these different statements and declarations, see Van der Loo 2016b.

${ }^{30}$ Council of the European Union (2016) Comprehensive Economic and Trade Agreement (CETA) between Canada, of the one part, and the European Union and its Member States, of the other part-Statements to the Council minutes, 13463/1/16 REV 1, http://data.consilium.europa. eu/doc/document/ST-13463-2016-REV-1/en/pdf, accessed 13 January 2017, at 14 (emphasis added).
} 
Moreover, statements by Germany, Poland, Belgium and Austria declare that these countries can exercise their right to terminate the provisional application as provided in CETA. ${ }^{31}$ This means that if one Member State refuses to ratify CETA, the provisional application will need to be terminated. This is remarkable because this implies that a Member State can block issues falling under exclusive EU competences. However, as argued above, this termination will not happen 'automatically', but would require the adoption of a Council Decision.

\subsection{The Way Out}

\subsubsection{The Decision of the Heads of State or Government, Meeting Within the European Council}

Although the referendum is not binding, Prime Minister Rutte stated that the ratification 'could not go ahead unhindered'. The Dutch government is now in the awkward position that it cannot ignore the outcome of the referendum, which would be a risky domestic move with general elections scheduled for March 2017, but it also would not want to block the conclusion of this landmark agreement. After months of informal negotiations and discussions in the Hague and Brussels, the Dutch government suggested in a letter on 31 October to the Dutch Parliament the option to ratify the agreement while accommodating the main concerns of the no-voters in a 'a legally binding solution'. ${ }^{32}$ This would be a 'Decision of the Heads of State or Government, meeting within the European Council'. This Decision would need to accommodate the concerns that were raised during the referendum by specifying that:

(i) The Association Agreement is not a stepping-stone to EU Accession

(ii) The Association Agreement does not include a 'collective security guarantee' and does not impose military cooperation on the Member States

(iii) The Association Agreement does not give Ukrainian employers access to the EU labour market

(iv) The Association Agreement does not include an obligation for financial support to Ukraine

(v) Strengthening of the rule of law and anti-corruption policies are key elements of the Association Agreement.

\footnotetext{
${ }^{31}$ CETA's provision on provisional application (i.e. Article 30.7(3)) is similar to the one in the EU-Ukraine Association Agreement, described above.

${ }^{32}$ Minister President M. Rutte and Minister of Foreign Affairs B. Koenders, Kamerbrief over referendum over het Associatieovereenkomst met Oekraïne, Ministerie van Buitenlandse Zaken, Nr. 2016Z19902, 31 October 2016.
} 
Such a 'Decision of the Heads of State or Government, meeting within the European Council' was finally adopted on 15 December 2016 and annexed to the European Council conclusions that were adopted that day. ${ }^{33}$ This Decision includes the five aforementioned points and states that it is 'in full conformity with the EU-Ukraine Association Agreement and the EU treaties'. It will take effect once the Netherlands has ratified the agreement and the Union has concluded it.

This option deserves some comments. First of all, it needs to be analysed to what extent it is actually 'a legally binding solution', as argued by the Dutch government. A 'Decision of Heads of State or Government, meeting within the European Council' is not something new. For example, a similar Decision was recently drafted in February 2016 in the context of adopting a 'new settlement for the United Kingdom with the European Union'. ${ }^{34}$ As rightfully noted in a an Opinion of the legal counsel of the European Council, such a Decision is

of an intergovernmental nature, not a decision of the European Council as an institution of the European Union under Article 15 TEU, within the meaning of the fourth paragraph of Article 288 TFEU, which would require to be based on a specific legal basis in the Treaties. ${ }^{35}$

Nevertheless, this draft Decision (which became defunct after the outcome of the Brexit referendum) was considered binding under international law because it constitutes 'an instrument of international law by which the 28 Member States agree on a joint interpretation of certain provisions of the EU Treaties and on principles and arrangements for action in related circumstances'. ${ }^{36}$ This argument is essentially based on Article 11 VCLT which states that the consent of a State to be bound by an agreement may be expressed by any means agreed by the parties and Article 31(3)(a) VCLT which mentions that a subsequent agreement between the

\footnotetext{
${ }^{33}$ European Council and Council of the European Union (2016) European Council Conclusions on Ukraine, 15 December 2016, http://www.consilium.europa.eu/en/press/press-releases/2016/12/15euco-conclusions-ukraine/, accessed 9 March 2017 (European Council Conclusions on Ukraine, 15 December 2016).

${ }^{34}$ European Council, Annex II to the Conclusions of the European Council meeting, Statement on Section A of the Decision of the Heads of State or Government, meeting within the European Council, concerning a new settlement for the United Kingdom within the European Union, EUCO 1/16, 19 February 2016. This draft Decision followed previous practice in comparable situations such as the Decision of the Heads of State and Government, meeting within the European Council, concerning certain problems raised by Denmark on the Treaty on European Union, which was adopted by the Heads of State or Government at Edinburgh, in the context of the European Council of 11 and 12 December 1992 or the Decision of the Heads of State or Government of the 27 Member States of the EU, meeting within the European Council, on the concerns of the Irish people on the Treaty of Lisbon, which was adopted in the context of the European Council of 18 and 19 June 2009.

${ }^{35}$ European Council, Opinion of the Legal Counsel, Draft Decision of the Heads of State or Government, meeting within the European Council, concerning a new settlement for the United Kingdom within the European Union (doc. EUCO 4/16) - Form, legal nature, legal effects and conformity with the EU Treaties, EUCO 15/16, 8 February 2016.

${ }^{36}$ Ibid.
} 
parties on the interpretation of a previous treaty is part of the context to be taken into account for interpreting that treaty.

The Opinion of the legal counsel with regard to the Decision on the EU-Ukraine Association adds that that the Decision needs to be regarded 'as an instrument of international law, by which the EU Member States agree on how they understand and will apply, within their competences, certain provisions of an act by which they are otherwise all bound'. ${ }^{37}$ It is therefore argued that this Decision is nothing less than an international agreement, ${ }^{38}$ especially considering that the European Council noted in its conclusions that the Decision 'is legally binding on the 28 Member States of the European Union, and may be amended or repealed only by common accord of their Heads of State or Government. ${ }^{39}$

However, the key difference between the Decision drafted in the 'UK context' and the one adopted with regard to the Ukraine Association Agreement is that the former was an instrument agreed upon by all the Member States on the interpretation of the EU Treaties, whereas the latter would be a unilateral interpretation of an international agreement with a third country (i.e. the EU-Ukraine Association-Agreement). As mentioned in Article 31(2) and (3) VCLT, a (subsequent) instrument can only constitute a legally binding interpretation of an international agreement when it is accepted by the other parties. Thus, as recognised in the Opinion of the legal counsel, the Decision would only be a legally binding instrument under international law, and bind the other parties, if it would be adopted jointly with, or formally accepted by, those other contracting parties. This would therefore not only require the consent of the Ukrainian government, but also of the EU. Noteworthy, in the context of the signature of CETA, the EU and Canada adopted a 'Joint Interpretative Instrument', which is a document that specifies how certain provisions of CETA need to be interpreted. ${ }^{40}$ Because both parties agreed to this Joint Interpretative Instrument, it is a legally binding instrument as foreseen in Article 31 VCLT. ${ }^{41}$ Whether Ukraine would agree with all the five points raised by the Dutch government is uncertain. Especially the membership-issue would be difficult for Ukraine to accept, even if the Association Agreement does not include an explicit membership perspective.

Thus, this Decision is binding in the sense that it imposes an interpretation of the Association Agreement on the Member States. Member States are legally bound by

\footnotetext{
${ }^{37}$ European Council, Opinion of the Legal Counsel, Draft Decision of the Heads of State or Government, meeting within the European Council, on the association agreement between the European Union and the European Atomic Energy Community and their Member States, of the one part, and Ukraine, of the other part, EUCO 37/16, 12 December 2016.

${ }^{38}$ Wessel 2016.

${ }^{39}$ European Council Conclusions on Ukraine, 15 December 2016.

${ }^{40}$ Council of the European Union, Joint Interpretative Instrument on the Comprehensive Economic and Trade Agreement (CETA) between Canada and the European Union and its Member States, 13541/16, 27 October 2016.

${ }^{41}$ This is explicitly recognised in the preamble of this document.
} 
it as concerns the way they understand the Association Agreement and the way they will apply it. ${ }^{42}$

It is also crucial to note that the Decision does not contradict or change any of the provisions of the Association Agreement. As noted by Advocate-General Saggio: 'a unilateral interpretation of the agreement made in the context of an internal adoption procedure cannot - outside the system of reservations - limit the effects of the agreement itself'. ${ }^{43}$ The five points in the Decision are indeed in conformity with the text of the agreement as they merely repeat what is or is not in the Association Agreement. Therefore, the Decision stresses that it is in full conformity with the EU-Ukraine Association Agreement'. ${ }^{4}$

\subsubsection{Alternative Options}

It appears that the two Dutch Chambers of Parliament will find this Decision a sufficient response to the outcome of the referendum. However, a swift approval should not be taken for granted at this point since the ruling coalition of Prime Minister Rutte has no majority in the Dutch Senate. Therefore, it is useful to map-out some alternative options for the Dutch Government.

In the worst-case scenario that the Dutch Parliament would reject the Decision of the Heads of State or Government as a response to the referendum and decide not to ratify the agreement, the Dutch government cannot only refuse to ratify the agreement for the Netherlands, it can also veto the EU's ratification of the agreement. As mentioned above, before the agreement can be concluded it must also be ratified by the EU on the basis of a unanimous Council Decision for the conclusion of the agreement. However, such a move would be difficult to reconcile with the principle of sincere cooperation, laid down in Article 4(3) TEU, which includes a mutual legal obligation for the EU and the Member States 'to assist each other in carrying out the tasks which flow from the Treaties'.

Another option would be that the EU, the Member States and Ukraine would adopt a kind of an 'adjusting protocol', which would delete the Netherlands as one of the contracting parties to the agreement. Such a strategy was adopted when Switzerland was not in a position to ratify the Agreement on the European Economic Area (EEA) in the early 1990s. This would mean that the Netherlands would not adopt the Approval Act (thus following the outcome of the referendum),

\footnotetext{
${ }^{42}$ The Opinion of the Legal Counsel even argues that the CJEU can use the Decision when interpreting the agreement in its reasoning to assess the intention of the Member States as to the scope of the commitments undertaken when becoming parties.

${ }^{43}$ Opinion of Advocate General Saggio, Case C-149/96 (Portugal v Council), ECJ, ECR I-08395, 25 February 1999. On this point, see also the judgment of the International Court of Justice, Case Concerning the Territorial Dispute (Libyan Arab Jamahiriya v Chad), ICJ, Judgment, 3 February 1994.

${ }^{44}$ This is also recognised in the Opinion of the Legal Counsel.
} 
but would still ratify the agreement at EU level in the Council. As a EU Member State, the Netherlands would still be bound by the non-mixed elements of the agreement (which covers the most important parts of the agreement). However, such an option could create legal uncertainty because, as mentioned above, it is not entirely clear which elements of the agreement fall under Member States' competences. Moreover, it would be very difficult to put a clear delineation of competences on paper, especially considering the broad scope of the agreement. Such an adjusting protocol would also require the formal approval (e.g. ratification) of the Ukrainian authorities, the EU and the EU Member States.

There are also some non-binding solutions possible. For example the Dutch government can adopt a unilateral statement, in which is specifies its 5 points, to be entered in the Council minutes. Such statements, which are for example also adopted by EU Member States in the context of CETA's signature, are not binding EU acts but form an integral part of the context in which the Council adopts the decision to conclude an agreement.

A last scenario would be the combination of several of the options described above.

\subsection{Conclusion}

The Decision of the Heads of State and Government is the easiest solution to solve the ratification deadlock of this landmark agreement. While being compatible with the Association Agreement and EU and international law, it addresses the main concerns that were raised during the referendum and binds the Member States (but not the Union and Ukraine). Unfortunately, a repetition of this Dutch non-ratification saga cannot be excluded. Although the Lisbon Treaty reduced the need for mixed agreements, it appears that mixity is here to stay. More than 30 mixed agreements have been concluded in the post-Lisbon era and if the CJEU will follow the recent Opinion of Advocate General Sharpston on the EU-Singapore Free Trade Agreement, who argued that this this trade agreement is mixed, ${ }^{45}$ the future for non-mixed EU trade agreements does not look bright. Considering the Eurosceptic climate in several Member States, it is almost bound to happen that a Member State will (threaten to) veto the conclusion of a mixed agreement in the future, for example in order to obtain some last-minute concessions. Whereas the creative legal solutions to these problems will provide interesting food for thought for scholars, they will further complicate the EU's treaty-making procedures and harm its role as a unified international actor.

\footnotetext{
${ }^{45}$ Opinion of Advocate General Sharpston: CJEU, Advocate General's Opinion in Opinion procedure 2/15, Press Release No 147/16, 21 December 2016.
} 


\section{References}

Flaesch-Mougin C, Bosse-Platière I (2014) L'application Provisoire des Accords de L'Union Européenne. In: Govaere I, Lannon E, van Elsuwege P, Adam S (eds) The European Union in the World. Essays in Honour of Marc Maresceau. Martinus Nijhoff Publishers, Leiden/Boston

Heliskoski J (2001) Mixed Agreements as a Technique for Organizing the International Relations of the European Community and its Member States. Martinus Nijhoff Publishers, Leiden/Boston

Maresceau M (2010) A Typology of Mixed Bilateral Agreements. In: Hillion C, Koutrakos P (eds) Mixed Agreements Revisited. The EU and its Member States in the World. Hart Publishing, Oxford/Portland

Rosas A (2014) Exclusive, Shared and National Competence in the Context of EU External Relations: Do Such Distinctions Matter? In: Govaere I, Lannon E, Elsuwege P, Adam S (eds) The European Union in the World. Essays in Honour of Marc Maresceau. Martinus Nijhoff Publishers, Leiden/Boston

Van Elsuwege P (2017) The Stabilisation and Association Agreement between the EU and Kosovo: An Example of Legal Creativity. Forthcoming

Van der Loo G (2016a) The EU-Ukraine Association Agreement. A New Legal Instrument for EU Integration without Membership? Brill Nijhoff, Leiden/Boston

Van der Loo G (2016b) CETA's Signature: 38 Statements, A Joint Interpretative Instrument and an Uncertain Future. CEPS Commentary. https://www.ceps.eu/publications/ceta's-signature-38statements-joint-interpretative-instrument-and-uncertain-future. Accessed 11 November 2016

Wessel R (2016) The EU Solution to Deal with the Dutch Referendum Result on the EU-Ukraine Association Agreement. European Papers. http://www.europeanpapers.eu/en/europeanforum/ eu-solution-deal-dutch-referendum-result-on-the-eu-ukraine-association-agreement. Accessed 7 March 2017 